\title{
aシヌクレイン脳内伝播の動物モデル
}

\section{鈴掛 雅美}

要約 : シヌクレイノパチーは $\alpha$ シヌクレインタンパク 質 $(\alpha \mathrm{S})$ の蓄積を特徵とする疾患の総称であり，パー キンソン病など進行性の神経変性疾患が含まれる。 ヌクレイノパチー患者の大多数は遺伝的背景のない 孤発性であり，その発症原因や疾患の進行メカニズム

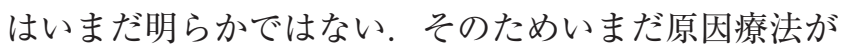
確立されていないという課題がある。この課題を克服 するには孤発性シヌクレイノパチーの発症㧍よび進 行過程を再現するモデル動物が必要である。近年, $\alpha \mathrm{S}$ 病理がプリオン様伝播により脳内で広がるという「プ リオン様伝播説」が提唱され，それを支持する実験 データが様々なグループから報告されている，われわ れは孤発性シヌクレイノパチーモデル動物の確立を目 標とし，野生型マウスを用いて $\alpha \mathrm{S}$ 病理掞よびその脳 内伝播を再現できないか検討を重ねてきた。その結果, 異常型構造をとった $\alpha \mathrm{S}$ を野生型マウスの脳内に接種 すると, 接種後 1 力月で $\alpha \mathrm{S}$ 病理の形成と脳内伝播が 観察されることを見いだした。病理は時間経過に伴い, 接種部位と神経接続のある領域に伝播した。 この現象 は野生型マウスだけでなく霊長類の 1 種であるコモン マーモセットでも同様に観察されたことから，ヒトで も起こりうる反応と考えられる。これらのモデル動物 は孤発性シヌクレイノパチー病態を一部再現したモデ ルであることから, 今後, 病態メカニズムの解明や新 規治療薬開発への応用が期待される.

\section{1. シヌクレイノパチー病態における $\alpha \mathrm{S}$ 蓄積と その脳内伝播}

シヌクレイノパチーにはパーキンソン病（Parkinson's disease : PD）のほか, アルッハイマー病に次いで頻 度の高い認知症であるレビー小体型認知症 (dementia with Lewy bodies : DLB), 多系統萎縮症 (multiple system atrophy：MSA）などの神経変性疾患が含まれ
る.これらの疾患は進行性であるが，なぜ「進行」す るのか，そのメカニズムは明らかではない，PD と DLB では $\alpha$ シヌクレインタンパク質 $(\alpha \mathrm{S})$ は神経細胞内 で Lewy body（LB）あるいは Lewy neurite (LN) と呼 ばれる病理構造物を形成して蓄積し, MSAでは主に グリア細胞の一種であるオリゴデンドロサイト内に蓄 積して glial cytoplasmic inclusion（GCI）と呼ばれる病 理構造物を形成している.

2003 年, 遺伝的背景を持たない孤発性 PDにおいて は LB，LN の脳内分布によって疾患のステージ分類が できることが報告された(1)。この報告によると，病 理分布は疾患初期（Stages I II）では延髄の迷走神経 背側核および嗅球に出現し, Stages III〜IVでは中脳黒 質や中間皮質にも広がり， Stages V〜VIになると新皮 質にも病理が出現するというステレオタイプな広がり 方を呈するという。これは $\alpha \mathrm{S}$ 蓄積病理の脳内伝播が 疾患の進行を決定づけていることを意味している。さ らに 2008 年には胎児ドパミンニューロンの移植術を 受けた PD 患者剖検脳解析から驚くべき現象が報告さ れた $(2,3)$. 剖検脳解析の結果, 移植した若い神経細 胞に $\alpha \mathrm{S}$ 蓄積病理が観察され, $\alpha \mathrm{S}$ 病理が周囲の神経細 胞から若い神経細胞へと伝播したことを強く示唆した.

上述の患者剖検脳を用いた研究から, $\alpha \mathrm{S}$ 病理が別の 神経細胞へと伝播すること，伝播が疾患の進行に媣く 関与することがわかってきた。つまり $\alpha \mathrm{S}$ 病理の脳内 伝播は疾患の進行過程の一部と捉えることができ, 脳 内伝播を抑制することができれば疾患の進行を抑制し うることからシヌクレイノパチーの新たな治療ター ゲットとして注目されている.

\section{2. $\alpha$ シヌクレインタンパク質}

$\alpha \mathrm{S}$ は 4 番染色体長腕に存在する $S N C A$ 遺伝子にコー

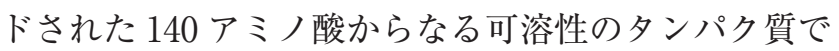

キーワード： $\alpha$ シヌクレイン，シヌクレイノパチー, プリオン様伝播，モデル動物

東京都医学総合研究所 認知症プロジェクト（†156-8506 東京都世田谷区上北沢 2-1-6)

E-mail: suzukake-ms@igakuken.or.jp＼cjkstart原稿受領日：2019 年 7 月 18 日, 依頼原稿 
あり（図 1）, 神経細胞内のシナプス前末端に多く局在 する。通常 $\alpha \mathrm{S}$ は明瞭な構造をとらないランダムコイ ル状で単量体として存在する (4) が, 患者脳内に蓄積 した $\alpha \mathrm{S}$ は重合し $\beta$ シート構造に富む不溶性のアミロ イド線維を形成している，アミロイド線維の形成領域 は $\alpha \mathrm{S}$ の中心領域 31〜109 a.a. である（図 1) (5). さら に, 蓄積 $\alpha \mathrm{S}$ に特徴的な翻訳後修飾が知られており, 129 番目のセリン残基のリン酸化 (6), $\mathrm{N}$ 末領域におけ る部分的なユビキチン化 (7) があげられる.

$\alpha \mathrm{S}$ は孤発性シヌクレイノパチーで蓄積しているが, $S N C A$ 遺伝子は家族性 PD および DLB の原因遺伝子の 1 つでもあり，これまでに 6 つの点変異と $S N C A$ 遺伝 子領域の重複（duplication または triplication）が報告 されている.すべての点変異はアミロイド線維形成領 域周辺 30 60 a.a. に集中しており，その多くは試験管 内でアミロイド線維形成を促進させる効果を示す. $S N C A$ 遺伝子領域の重複は野生型 $\alpha \mathrm{S}$ のタンパク質発 現量の増加を引き起こすが, $\alpha \mathrm{S}$ タンパク質濃度の上昇 はアミロイド線維形成反応を促進させる因子であるこ と, triplication 家系では duplication 家系より発症年齢

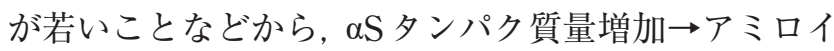
ド線維形成促進 $\rightarrow$ シクレイノパチー発症, という発 症への流れが予想できる。これらの知見を統合すると， $\alpha \mathrm{S}$ の構造変化, すなわちアミロイド線維形成がシヌク レイノパチー発症に梁く関与していることがわかる.

\section{3. $\alpha \mathrm{S}$ のプリオン様伝播}

シヌクレイノパチー患者脳内で $\alpha \mathrm{S}$ 病理が伝播する メカニズムの詳細は明らかではないが，プリオンの増 幅・伝播機構と類似した「プリオン様伝播説」が提唱 されている（図 2)。プリオンの増幅・伝播では，異常 型構造を持つプリオンタンパク質が生体内で形成され ると正常型構造のプリオンタンパク質と相互作用し, 鋳型として機能し正常型を異常型構造に変換し，その 結果異常型プリオンが増幅することが知られている. 異常型プリオンタンパク質は $\beta$ シート構造を持つアミ ロイド線維構造を取って抢り, シヌクレイノパチー患 者脳内に蓄積した $\alpha \mathrm{S}$ との類似性をうかがわせる。 さ

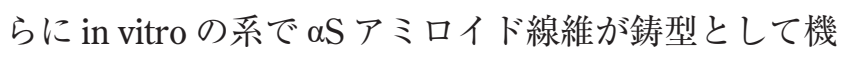
能する「シード依存性のアミロイド増幅反応」が進行 することが報告されていた $(8)$. 可溶性の $\alpha \mathrm{S}$ タンパク 質溶液を $37^{\circ} \mathrm{C}$ で静置してもアミロイド線維はほとん ど形成されないが，そこに予め作製した微量の $\alpha \mathrm{S} ア$ ミロイド線維を加えるとアミロイド線維形成が著しく 促進される (8).この現象は培養細胞内でも観察する ことができる. SH-SY5Y 細胞に $\alpha \mathrm{S}$ を過剩発現させて

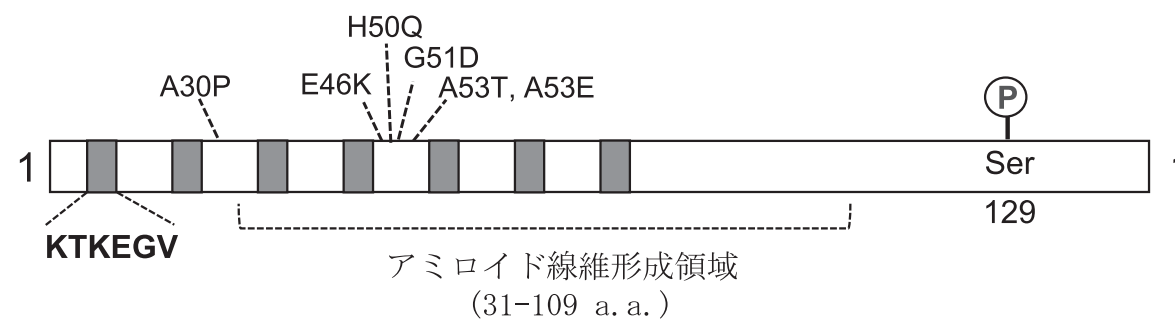

図 1 aシヌクレインタンパク質

aS は 140 ア三ノ酸からなり, N末側領域にKTKEGV からなる不完全な7つの繰り返し配列を有する。家族性 PD, DLB 家系で見出された $6 つ$ こスセンス変異（A30P, E46K, H50Q, G51D, A53E, A53T) はN 末領域に集中している. アミロイド線維形成領域は中心領域 37〜 109 a.a. であり, シヌクレイノパチー患者脳内で蓄積した $\alpha$ S は 129 番目のセリン残基がリン酸化を受けている.

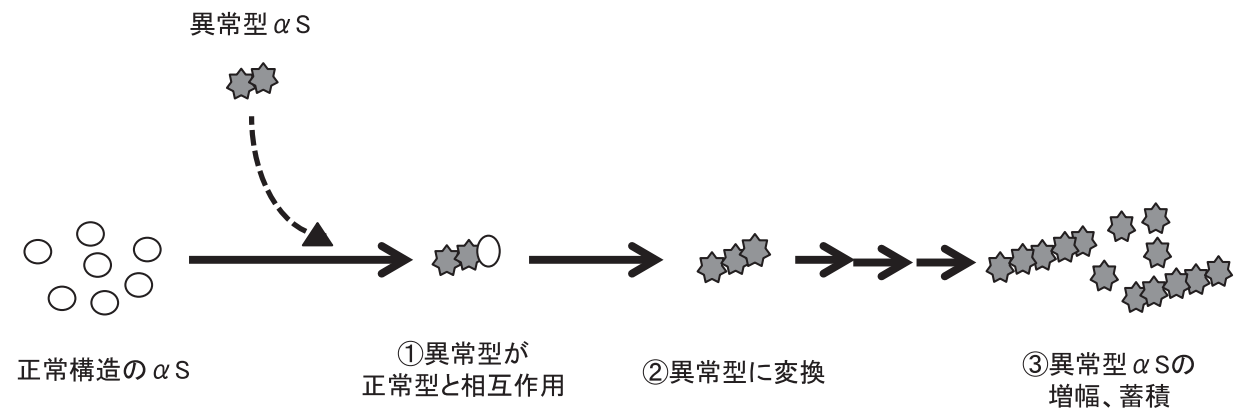

図 2 aS アミロイド線維のプリオン様伝播機構模式図

微量の異常型 $\alpha S$ (ア三ロイド線維) が存在すると, (1)正常型 $\alpha S$ と相互作用し, (2)正常型 $\alpha S$ が異常型構造に変換される. この反応が繰り返さ れることにより (3)異常型 $\alpha S$ の増幅が増幅され， $\alpha S$ 蓄積が急速に進行する. 
も不溶性 $\alpha \mathrm{S}$ は形成されないが, $\alpha \mathrm{S}$ 過剩発現細胞にリ ポフェクション試薬を用いて微量の $\alpha \mathrm{S}$ アミロイド線 維を導入すると 3 日程度で不溶性の $\alpha \mathrm{S}$ アロロイドが 形成されて蓄積する (9)。この細胞モデルにおいて蓄 積 $\alpha \mathrm{S}$ はセリン 129 のリン酸化, 部分的なユビキチン 化を受けており患者脳に蓄積した $\alpha \mathrm{S}$ と同様の翻訳後 修飾を受けていた。これはシード依存的なアミロイド 増幅反応により培養細胞内に蓄積した $\alpha \mathrm{S}$ が患者脳内 と同様のプロセッシングを受けたことを示している. そこでわれわれは $\alpha \mathrm{S}$ アミロイド線維導入によるプリ オン様伝播が生体内でも進行するのではないかと考え, 動物モデルの作製に着手した。

\section{4. シヌクレイノパチーモデルマウス}

従来, シヌクレイノパチーモデルマウスは変異型 $\alpha \mathrm{S}$ を過剩発現させたトランスジェニックマウスが主で あった．しかしながらシヌクレイノパチー患者の大多 数は孤発性であることから変異型 $\alpha \mathrm{S}$ は有しておらず, 過剩発現もしていない，そのため孤発性シヌクレイノ パチー病態は野生型マウスでも再現できると考え, プ リオンの感染実験で用いられている手法を用いて検討 した. プリオンの感染実験では異常型プリオンを含む 試料を実験動物の脳内に接種し, 感染の有無を病理評 価や生存期間短縮等によって判断できる。 そこであら

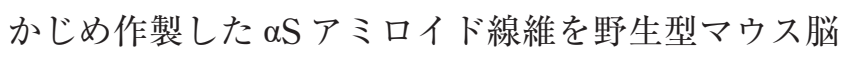
内に接種し病理評価を行った（図 3).

野生型マウスの片側中脳黒質に様々な $\alpha \mathrm{S}$ (リコンビ ナントヒト $\alpha \mathrm{S}$, マウス $\alpha \mathrm{S}$ の可溶性モノマーあるいは アミロイド線維, DLB 患者脳由来不溶性画分）を接種 した(10). 接種後 $3,6,15$ 力月後に病理評価を行った 結果， $\alpha \mathrm{S}$ アミロイド線維または DLB 患者脳不溶性画 分を接種した群ではリン酸化 $\alpha \mathrm{S}$ 抗体陽性の病理が観 察され，時間経過に伴い反対側への伝播も観察された. $\alpha \mathrm{S}$ 病理伝播は中脳黒質と神経連絡のある領域では早 期から観察された。蓄積病理は神経細胞内に存在して おり,さらにユビキチン, p62 抗体陽性であった。一
方, 可溶性 $\alpha \mathrm{S}$ モノマー接種群では 15 力月経過後にお いても病理形成は観察されず，可溶性 $\alpha \mathrm{S}$ はシードと して機能しなかった．ヒト $\alpha \mathrm{S}$ 線維を脳内接種したマ ウス脳から界面活性剂サルコシルに対する不溶性画分 を回収し，イムノブロット解析を行ったところ, 接種 試料であるヒト $\alpha \mathrm{S}$ 線維は接種後 1 週間で分解され検 出レベル以下に減少した。接種後 3 カ月が経過すると, リン酸化・ユビキチン化された内在性マウス $\alpha \mathrm{S}$ の蓄 積が認められた。この結果は, 接種試料に含まれるヒ 卜 $\alpha \mathrm{S}$ 線維が蓄積したのではなく, 内在性のマウス $\alpha \mathrm{S}$ が不溶性を獲得し翻訳後修飾を受けて蓄積したことが 明らかとなった(10)。 $\alpha \mathrm{S}$ ノックアウトマウスへの脳内 接種では病理形成・伝播とも見られないこと(10-12) も, この結果を支持している. さらにプリオン感染実 験で観察されるような ‘種の壁’ が $\alpha \mathrm{S}$ 伝播においても 存在するか, 接種試料によって野生型マウスに対する 病理誘導能が異なるか比較した(10)。 マウスの $\alpha \mathrm{S} ア ミ$ ロイド線維を接種した群（n=8）では全個体で接種側, 反対側ともリン酸化 $\alpha \mathrm{S}$ 抗体陽性病理が観察された. 一方, ヒト $\alpha \mathrm{S}$ のアミロイド線維を接種した群 $(\mathrm{n}=24)$ では, 22 匹 $(91.6 \%)$ で接種側に病理が観察されたの に対し, 反対側への $\alpha \mathrm{S}$ 伝播がみられた個体は 19 匹 (79.2\%) と, マウス $\alpha \mathrm{S}$ アミロイド線維接種群に比べ て低かった。この結果は野生型マウスを宿主とした場 合, ヒト $\alpha \mathrm{S}$ 線維よりもマウス $\alpha \mathrm{S}$ 線維の方が $\alpha \mathrm{S}$ 病理 誘導・伝播の効率が高いことを示唆しており， $\alpha \mathrm{S}$ 伝播 においてもプリオンと同様の “種の壁”や“株”が存 在すると考えられる. ヒト $\alpha \mathrm{S}$ とマウス $\alpha \mathrm{S}$ のアミ酸 配列は $95 \%$ の相同性があり極めて似ているが，7つの アミノ酸残基が異なるだけでシード能の差を生むよう である。一方 DLB 患者脳由来の不溶性画分を接種し た群 $(\mathrm{n}=14)$ では，接種側に病理がみられた個体は $50 \%$ にどまり，反対側への伝播が見られた個体は 1 個体 $(7.1 \%)$ ，合成 $\alpha \mathrm{S}$ 線維接種に比べて病理誘導・ 伝播の効率が低かった。これは患者脳不溶性画分に含

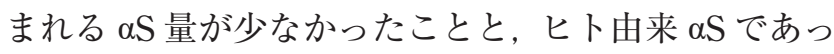

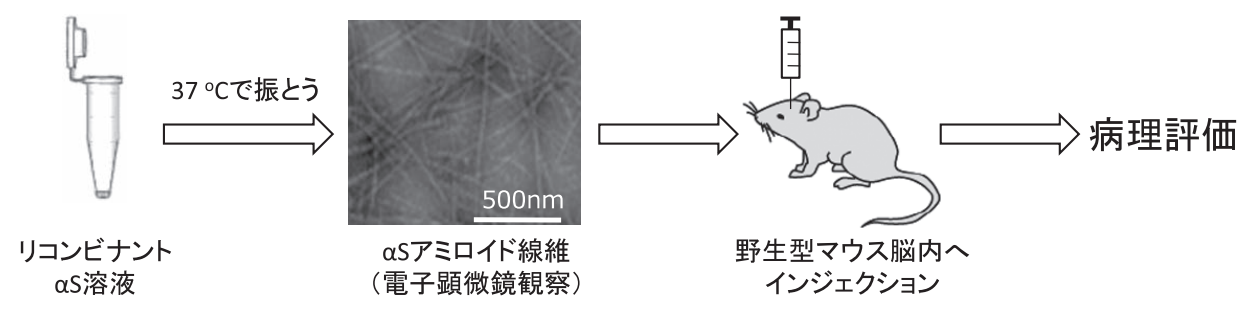

図 $3 \alpha S$ 伝播モデルマウス作製方法

リコンビナント $\alpha \mathrm{S}$ 溶液を $37^{\circ} \mathrm{C}$ で振とうすると数日で $\alpha S$ アミロイド線維が形成される. 作製したアミロイド線維を野生型マウス脳内にイン

ジェクションし，数カ月間飼育したのち，aS リン酸化抗体を用いた免疫組織染色により $\alpha S$ 病理形成および脳内分布を解析する. 
たことが原因と考えている．それでも50\%の個体で 病理誘導が認められたことは患者脳由来の不溶性 $\alpha \mathrm{S}$ もプリオン様伝播能を有することを示している， $\alpha \mathrm{S}$ 伝播様式については, 中脳黒質に接種した場合には扁 桃体中心核や分界条といった直接神経連絡のある部位 に伝播しており，接種部位を線条体にすると扁桃体や 中脳黒質に分布がみられた。また嗅内野に接種すると 海馬，海馬采，中隔核に伝播がみられた (12)。このこ とは $\alpha \mathrm{S}$ 病理の伝播は接種部位に依存して変化するこ と,さらに神経回路を介している可能性を強く示唆し ている.

\section{5. シヌクレイノパチーモデルマーモセット}

上述のように野生型マウス脳内では $\alpha \mathrm{S}$ のプリオン 様伝播, すなわちシード依存的なアミロイド増幅反応 が進行したが，ヒトなど霊長類においても $\alpha \mathrm{S}$ 伝播が 起きうるか疑問が残った。そこで筆者らは実験動物と して確立されているコモンマーモセット（Callithrix

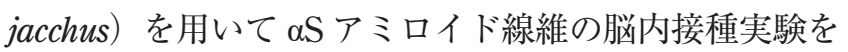
行った。コモンマーモセットは体重約 $400 \mathrm{~g}$, 脳重約 $7 \mathrm{~g}$ の小型の霊長類であり, ヒトに近い脳構造を有して

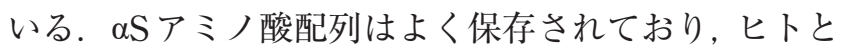
$97.2 \%$ の相同性を有する. 内因性のマーモセット $\alpha \mathrm{S}$ がプリオン様伝播機構によって蓄積するか調べるため, 接種試料としてマウス $\alpha \mathrm{S}$ アミロイド線維を使用した. LB509 抗体（抗ヒト $\alpha \mathrm{S}$ 認識抗体）はマウス $\alpha \mathrm{S}$ には反

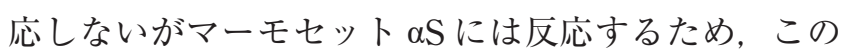
抗体を用いると接種試料とマーモセット $\alpha \mathrm{S}$ を区別す ることができる。マーモセットの片側線条体に合成 $\alpha \mathrm{S}$ アミロイド線維を接種し 3 力月後に病理評価を 行った結果，接種部位だけでなく，接種部位から離れ た領域にもリン酸化 $\alpha \mathrm{S}$ 抗体陽性, ユビキチン, p62 陽 性の病理が多数形成されていた (13)。 $\alpha \mathrm{S}$ 蓄積病理は LB509 抗体陽性であり内因性のマーモセット $\alpha \mathrm{S}$ が蓄 積していた。さらに接種側の中脳黒質においてドパミ
ン神経マーカーであるチロシン水酸化酵素の免疫染色 性に低下傾向がみられた(13)。以上の結果から，霊長 類であるコモンマーモセット脳内に扔いて $\alpha \mathrm{S}$ のプリ オン様伝播が進行し, それに伴い神経細胞脱落が誘導 されることが示唆された．現在このモデルを用い， $\alpha \mathrm{S}$ 病理伝播により運動機能・行動解析に異常がでるか検 討を進めている.

\section{6. まとめ}

$\mathrm{PD}$ 剖検脳の解析から $\alpha \mathrm{S}$ 蓄積病理の脳内伝播が疾患 の臨床症状と相関することが示され， $\alpha \mathrm{S}$ 脳内伝播がシ ヌクレイノパチーの進行を規定していることが分かっ てきた。 $\alpha \mathrm{S}$ 伝播モデルマウスはシヌクレイノパチー 進行過程の解明や, 新規治療法のスクリーニングに極 めて有用と考えられる。しかしながらこのモデルでは $\alpha \mathrm{S}$ 蓄積は神経細胞内に形成されるため $\mathrm{PD}, \mathrm{DLB}$ 病態 のモデルにはなるが，オリゴデンドロサイトに $\alpha \mathrm{S}$ 蓄 積がみられるMSAのモデルにはならないという課題 も残っている. 今後 MSA病態モデル動物の構築が待 たれる，それにより PD，DLB とMSAに打ける病態 メカニズムの違いや疾患ごとの治療戦略が確立される ことが期待される。

著者の利益相反 : 開示すべき利益相反はない.

\section{文献}

1) Braak H, et al. Neurobiol Aging. 2003;24:197-211.

2) Li JY, et al. Nat Med. 2008;14:501-503.

3) Kordower JH, et al. Nat Med. 2008;14:504-506.

4) Araki K, et al. Sci Rep. 2016;29:30473.

5) Miake H, et al. J Biol Chem. 2002;277:19213-19219.

6) Fujiwara H, et al. Nat Cell Biol. 2002;4:160-164.

7) Hasegawa M, et al. J Biol Chem. 2002;277:49071-49076.

8) Han H, et al. Chem Biol. 1995;2:163-169.

9) Nonaka T, et al. J Biol Chem. 2010;285:34885-34898.

10) Masuda-Suzukake M, et al. Brain. 2013;136:1128-1138.

11) Luk KC, et al. Science. 2012;338:949-953.

12) Masuda-Suzukake M, et al. Acta Neuropathol Commun. 2014; $2: 88$.

13) Shimozawa A, et al. Acta Neuropathol Commun. 2017;5:12. 


\title{
Animal models of synucleinopathies: prion-like propagation of alpha-synuclein in wild-type animals
}

\author{
Masami Masuda-Suzukake \\ Dementia project, Tokyo Metropolitan Institute of Medical Science
}

\begin{abstract}
Accumulation of insoluble alpha-synuclein $(\alpha \mathrm{S})$ is a pathological hallmark of some progressive neurodegenerative diseases including Parkinson's disease, dementia with Lewy bodies, and multiple system atrophy, collectively termed synucleinopathies. In diseased brain, $\alpha \mathrm{S}$ forms $\beta$-sheet-rich amyloid fibrils and it is accumulated in neurons or glial cells. A growing body of evidence suggests that spreading of $\alpha \mathrm{S}$ pathology occur by prion-like propagation mechanisms. Our study revealed that intracerebral injection of synthetic $\alpha \mathrm{S}$ amyloid fibrils into wild-type mice induced prion-like propagation of $\alpha \mathrm{S}$ pathology at 1 month post injection, while injection of soluble $\alpha \mathrm{S}$ did not induce $\alpha \mathrm{S}$ pathology. Furthermore, injection of $\alpha \mathrm{S}$ amyloid fibrils into $\alpha \mathrm{S}$ knockout mice failed to induce any pathologies. We also have demonstrated that intracerebral injection of $\alpha \mathrm{S}$ amyloid fibrils into small primates, adult common marmosets, resulted in spreading of $\alpha \mathrm{S}$ pathologies and loss of TH-positive neurons. These in vivo experiments clearly indicate that $\alpha \mathrm{S}$ amyloid fibrils has prion-like properties and it propagates through neural networks. The underlying mechanisms of $\alpha \mathrm{S}$ propagation are poorly understood, however, $\alpha \mathrm{S}$ propagation model animals would be useful in elucidating pathogenetic mechanisms and developing disease-modifying drugs for sporadic synucleinopathies.
\end{abstract}

